\title{
Sustainable cities in tropical climates: presentation of the "Beauséjour" case study in Reunion Island
}

\author{
P. Rivière ${ }^{1}$, M. Verges ${ }^{2}$, M. Dimou ${ }^{1}$ \& F. Garde ${ }^{1}$ \\ ${ }^{1}$ PIMENT Laboratory, University of Reunion Island, France \\ ${ }^{2}$ CBo Territoria, Reunion Island, France
}

\begin{abstract}
Reunion Island is a small French island located in the Indian Ocean, 900km off the East coast of Madagascar in the Southern hemisphere. The population is 800,000 inhabitants and will rise to one million in 20 years. The total area of the island is $2,500 \mathrm{~km}^{2}$ with only $313 \mathrm{~km}^{2}$ available for urbanization. The climate is tropical with a summer season and a mild winter season. Only a few sustainable cities' projects in tropical areas have been listed so far. The purpose of this study is thus to present the - in progress - Beauséjour sustainable town project. The plan is to build a new town in a $0.8 \mathrm{~km}^{2}$ area in the North of Reunion Island, with 2,300 residential units. The whole town is being built by a local private CBo Territoria whose business model allows an original planning and management of sustainable cities. The study mainly deals with the aspects of planning and managing the sustainable town. It both retraces the regional rules context that lead to the project and how the town is being planned and managed; this includes the iterative reflection between the developer-contractor, real-estate developers (housing and services sector) and assets and properties management. One of the original aspects in the methodology is how the management of the city is questioned regarding the project itself. The expected results covert the three pillars of the sustainable development. The main objective is the creation of a living town center, where the all the five functions will "collide". This led us to the social diversity and the transportation aspects where the project is acting as an innovative catalyzer and lastly the environmental part with green design building and multiple green spaces.
\end{abstract}

Keywords: sustainable town, urban planning and management, tropical climates, Reunion Island, green design, green spaces. 


\section{Introduction}

Reunion Island is a small piece of land belonging to France in the Indian Ocean. It is located $900 \mathrm{~km}$ east of Madagascar and $230 \mathrm{~km}$ west of Mauritius. Population is up to 800,000 inhabitants and will reach $1 \mathrm{M}$ by 2030 . Until 2008 the GDP growth was more than $5 \%$ per year: the territory is dynamic both economically and socially.



Figure 1: $\quad$ Location of Reunion Island in the Indian Ocean (Google Earth).

The main problem is to create the housing needed by 2030, indeed, the area of the island is $2500 \mathrm{~km}^{2}$ but only $313 \mathrm{~km}^{2}$ are available for urbanisation. The reason is the interior of the island is a very high mountainous area, besides the $2 / 3$ of the island is both classified as natural reserve and as UNESCO world heritage. Climate is tropical with a summer season and a mild winter season with temperature up to $18^{\circ} \mathrm{C}$ (coast level), pluviometry is very high during the hot season; Reunion Island holds a world record of pluviometry from 12 hours to 15 days [1]. Considering all the facts, the climate, the population rate of growth, the lack of land, and the goal of natural preservation, Reunion Island is a case in point to define how the tropical sustainable city may be planned, managed and built.

The Beauséjour case study enlightens a different way of planning and managing the sustainable city. Beyond the carefulness to the environmental aspects, which was often the primaries objectives of sustainable town projects [2], the economic and social aspects of the project shouldn't be ignored. Putting in perspectives all these pillars lead the contractor owner to develop an original way of conducting the project. This alternative way was possible due to the unique business model of the contractor owner who has three components, 
developer contractor, real estate developers and assets and properties management.

\section{The Beauséjour project context}

Covering a 200 acre (80 ha) area, the project is planned to respond regional stakes: building housings upon condition that it creates an urban density compatible with a rational land use. The primary objective is to avoid urban sprawl which is corresponding to the compact city concept.

\subsection{Urban and regional planning instrument}

In Reunion Island where French laws apply there are four documents which successively draw the regional urban project to the municipality urban project. The general principle is the compatibility between the instruments.

The Regional land use documents (Schéma d'aménagement Régional SAR), provided by the regional council; the territorial coherence schematic (Schéma de Cohérence Territorial, SCoT), inter municipality scale; the local housing program (Programme Local de l'habitat, PLH), inter municipality scale; The Local Urbanism Plan (Plan Local d’Urbanisme, PLU), municipality scale.

About Beauséjour site, the first regional land use document (1995) has identified the area of the project as an urban vocation land. More over the territorial coherence schematic defined that the projected urban density will be up to 12 housing-units per acre (30 housing units per hectare). Lastly the local housing program fixed the objective of 2000 housing-units.

The interesting thing about the last level, the local urbanism plan, is that the instrument's prescriptions are iteratively defined by the operational project. This particularity allows the process to be innovative.

\subsection{Pre-operational context}

The Developer-contractor owns $85 \%$ of the land; due to those parameters two scenarios were possible: A response to the local housing program and urban density or coming up with a wider response based on an urban project with a mix of functions aiming at structuring all the nearby neighbourhoods. Translating those stakes into the project led to the design of a town centre.

The first objectives of the new town do not deal with environmental features; the project is being built according to the local area requirements. This does not mean that environmental features shouldn't be integrated, at the programming step, the principle of "Green Urbanism” must be part of the project during these pre-operational studies. Those aspects are very important because they are leading to the project economic viability. Anyway as Steffen Lehmann says "Green Urbanism is common sense urbanism. In the future, Green Urbanism has to become the norm for all urban developments" [3]. Environmental and green issues must be part of the urban project, but they have to be considered in a holistic vision resting upon urban problematic. 


\subsection{The operational urban project}

As the first objective is functional mix, the mobility issue will be a structuring component of the project. These two elements are the keystone of a green urbanism holistic vision. However, the operational context has to take into account of the green urbanism, more specifically the emphasis is on what Peter Newman called "The biophilic city” [4]. Although Béauséjour does not integrate the whole concept (for example, the biomass part), the conception's multidisciplinary team has balanced most of "green urbanism" points and the developer contractor took decisions based on three criteria: law and regulation, the financial, the technical feasibility (including the urban management parameter).

The internal mobility framework in order to be sustainable has to allow soft modes of transports. In order to apply the urbanism methodologies the soft transport modes framework is linked to the green framework. The purpose is not just about creating a friendly environment for people, it contributes to cooling the site, mitigating the UHI, both the pedestrian thoroughfare and the urban perimeter [5, 6], it also creates news biotopes for birds and other fauna [7] which participates to an ecological restoration dynamic (figure 2).

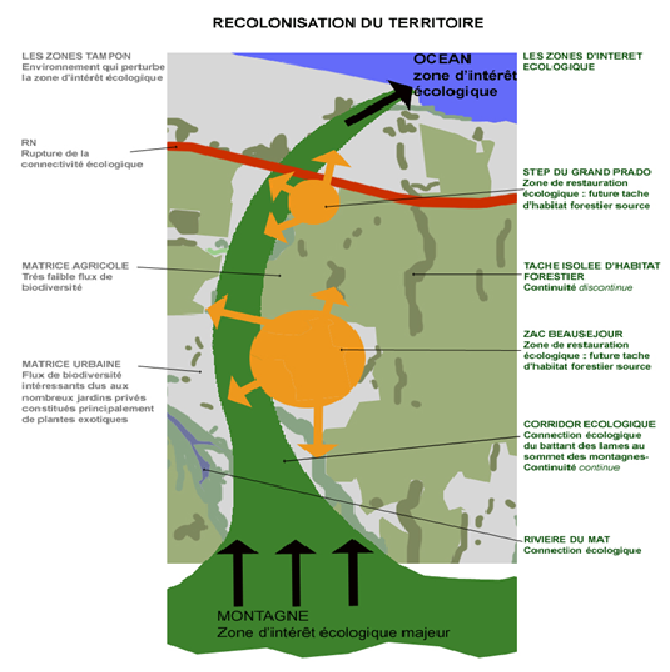

Figure 2: $\quad$ Ecological restoration strategy (Michèle Adolphe, Leu Réunion).

The holistic vision does not only limit to the fusion of the soft transportation mode and the green framework, it also concerns the blue framework (figure 3).The goal is to create synergy between the green and the blue framework. The thinking of the aerial rain water management allows the green public spaces to maximize their water needs taking advantage of the sites' topography. 


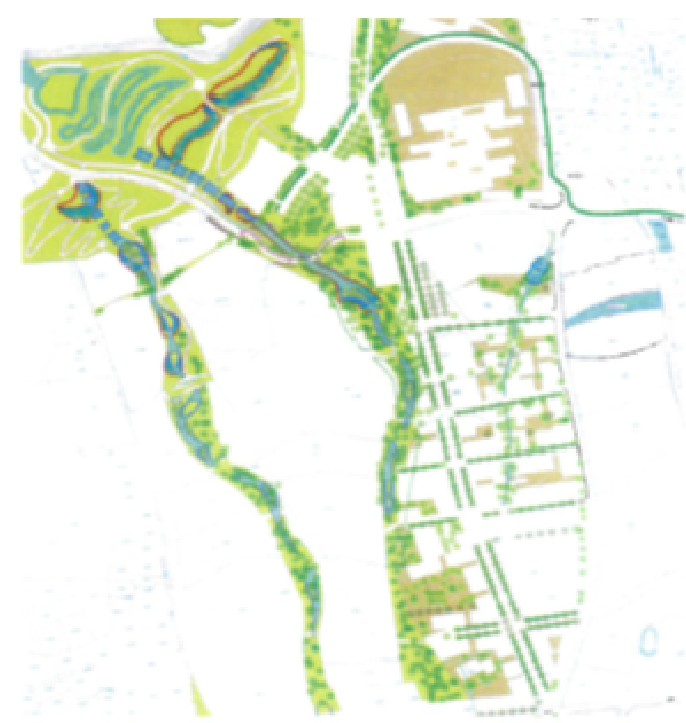

Figure 3: $\quad$ Beauséjour green and blue frameworks (Tekhnê, Architectes).

Adding all those parameters, it is relevant to say that the whole project is based upon the constraint: Mixing all the elements and combining their benefits both direct and indirect, soft transportation, green and blue frameworks. This is what is contributing to Beauséjour's sustainability.

\section{Changing the way of conducting the project}

\subsection{Project's temporality}

With nearly 200 acres, 2,300 housing units, shops, offices and public services, the project's construction phase is planned to last between six to ten years.

This temporality provides some flexibility in the project's management, it allows numerous and consistent adjustments. The search of sustainability is heading up to some kind of instability so the project is technically harder, all the actors have to adapt to the changes. These types of change in the management are leading to concurrent engineering.

For example, the aspects which dictated the redesign of the town centre are not environmentally related but based on social and economic necessities. The question was simple, how to design a liveable and viable economic town centre? This question as simple as it is called for economics, spatial locations of the shop studies and new urban studies to find the accurate urban form that will fit a compact tropical city town centre. As the design team was solving this question, the environmental issues were considered with a holistic vision of the question asked. Indeed, all along the shops, the mall is design with indigenous and endemic tall standard trees providing shading and evaporative cooling [8]. Those characteristics will improve the thermal comfort sensation of the clients and will really create the living town centre. 


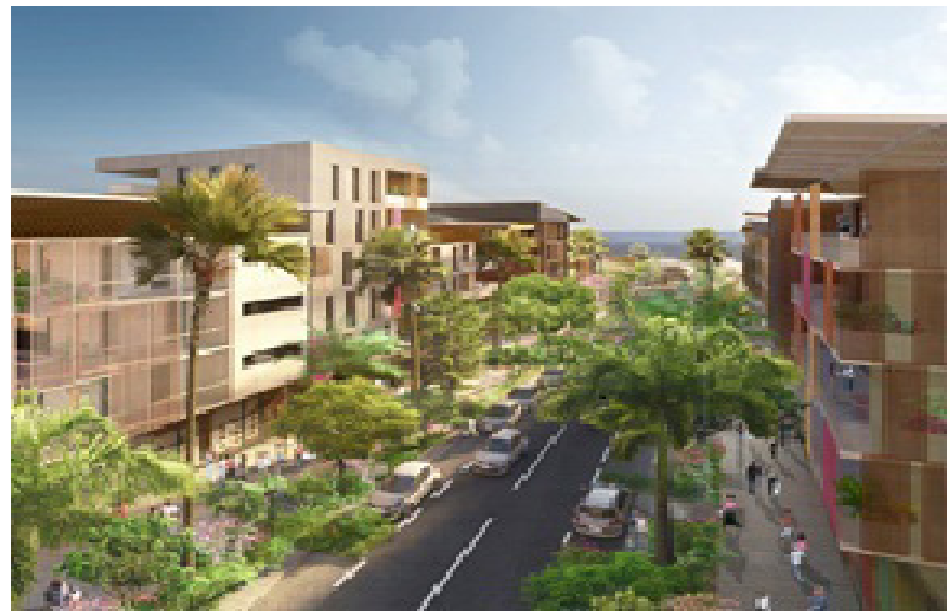

Figure 4: Béauséjour future town centre (Tekhnê Architectes).

\subsection{A two level perimeter}

The reflection on the project's area takes into account of two different levels:

- The neighbourhood scale, soft transport mode designed;

- The nearby existing neighbourhood and the economic-space scale: business activity, commercial and airport area.

The urban project is designed to ensure the complementarity of the areas instead of balancing the weakness of the new project. The project is not based on spatial competition between the areas but complementarity.

Taking into account of the larger perimeter level (the second one) is improving the mobility strategy, benefitting to both the town and the micro-area. As the projects site is well located, the multimodal exchange location is becoming the key point of the bus transit strategy of the micro-area. Coupling the multimodal exchange point with segregated lanes is creating a viable alternative for private cars. This won't make the town car free but the inhabitants will have a choice of an alternative mobility which they did not have before.

The two scales of reflection enriched each other, providing win-win effects. The sustainability here is the way of structuring the territory's mobility and the alternative mobility inside the project. Mobility is considered on both inside and outside of the town, it has to be designed as one strategy.

\section{Setting up the project: distinguishing features of the contracting owner}

The project's originality and strength is built upon the four branches of the company. All the steps of the town's creation process are represented.

- The developer contractor who is mastering the urban project and sells buildings rights; 
- $\quad$ Two distinctive real-estate developer branches, housing and business.

- $\quad$ Assets and properties management.

The classic way of conducting the project is sequential, the developer contractor sells with prescriptions plots or clusters to a real estate developer; then the buildings are managed by the owner or asset and properties management.

The main innovation in managing Beauséjour sustainable town is the concurrent action of the four branches. The developer contractor and the real estate branches are able to build and share the vision of the urban project together. This way of managing the projects allows a synergetic action on the environmental issues. Furthermore the contribution of the assets and properties management can point out some design faults which often lead to inefficiency in both building and urban management.



Figure 5: Creation and management process of the sustainable town.

Ultimately, every step of the project is conducted through an iterative and transversal way. The sustainable town is no more a technical but a managing process innovation. The managing process is allowing the optimal consideration of the environmental issues.

\section{Technical and environmental approach and advocacy planning}

The technical and environmental approaches are based on two things: the tropical climate, with its specificity and the nature preservation regarding the stakes of the rate of endemic species in Reunion [9]. 
Thanks to the original business model of the contractor owner, the environmental approach can be split in three levels: On the urban project itself, on the building and on the building operations and urban management. The project's strength is the mix of the urban and construction scale which allows an optimal consideration of the environmental issues. The focus of that interaction is the symbiotic relationship between public and private spaces. The junction public/private spaces with the vegetal harmony are the primary goal (figure 4). The objective here is to maximize the "tropical forest" effect which is one the important aspects of the tropical city [10]. Although noticeable, the rainwater management, the public storm water system is designed to optimise the leakage rate induces constraint for constructible plots.

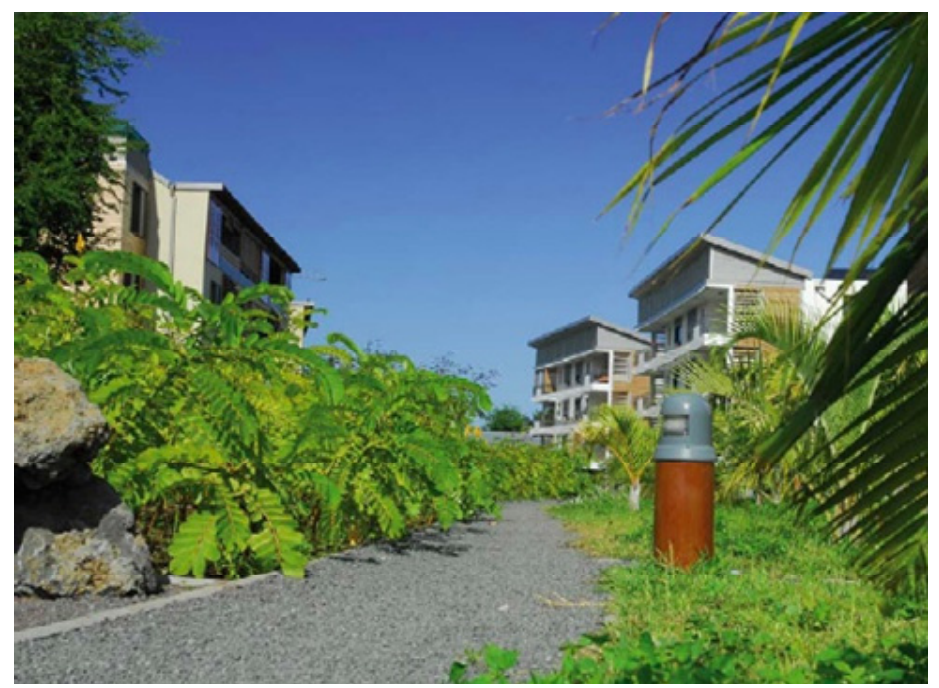

Figure 6: Attempt of creating a "tropical forest" in the town (La Cocoteraie, CBo Territoria).

Beyond the previous elements, contractor owner has committed himself on several elements (table 1).

Last but not least, advocacy planning is becoming part of the project. The main difficulty of advocacy planning is to make the difference between citizen participation that fall within the legal compulsory disclosure and the real and constructive application which belongs to the top of the famous Sherry Arnstein participation ladder [11]. The developer contractor has initiated an approach aiming a "good living together", allowing citizens to interact with the contractor owner, matching the $5^{\text {th }}$ rung of Sherry Arnstein Ladder: Placation.

The link between advocacy planning and environmental issues is a tremendous thing, Joachim Elbe the famous EVA-Lanxmeer urbanist said about his project that "if there's one thing to understand about EVA-Lanxmeer is that urbanisation of an ecological sensible site can only be made with the cooperation 
Table 1: Beauséjour's urban and building sustainable elements.

\begin{tabular}{|l|l|}
\hline \multicolumn{1}{|c|}{ Urban } & \multicolumn{1}{|c|}{ Building } \\
\hline Aerial rainwater management & Bioclimatic design (before the law's) \\
\hline $\begin{array}{l}\text { Green, blue and soft transportation } \\
\text { mode frameworks }\end{array}$ & $\begin{array}{l}\text { Constant desire to improve buildings' } \\
\text { efficiency and quality }\end{array}$ \\
\hline Bioclimatic Masterplan & $\begin{array}{l}\text { Thermal studies for business buildings } \\
\text { (local technical guidelines PERENE) }\end{array}$ \\
\hline $\begin{array}{l}\text { Tropical green city strategy, not } \\
\text { green spaces strategy. Indigene and } \\
\text { endemic are privileged }\end{array}$ & $\begin{array}{l}\text { Innovation with a Natural ventilation } \\
\text { system tested on 250 housing units. }\end{array}$ \\
\hline $\begin{array}{l}\text { Cooperation an collaboration with } \\
\text { municipality and various urban } \\
\text { actors }\end{array}$ & $\begin{array}{l}\text { Solar hot water (housing), Solar panel } \\
\text { (Business building }\end{array}$ \\
\hline
\end{tabular}

of the future inhabitants” [12]. As we are facing global warming and climate challenges, more stretches of lands are at risk on the environmental level, this is why it is relevant to integrate bioclimatic-sensitive design but also having an accurate advocacy policy.

\section{Conclusion}

Beauséjour is the kind of the prototype of the Sustainable compact tropical city. It represents an efficient and alternative use of land between urban sprawl and high rise urbanism. As we have seen it provides urban centres which are hallmarks off the polycentric city [13] and allows structuring disseminated neighbourhood into an organized urban area. These are the primary objectives of urbanism, adding those to the specific tropical context lead the project to consider environmental issues. The classic pitfall is to add environmental objectives to a classic project during the design phase or later. The way of thinking here is different; the point is to mix environmental issues with the urban project objectives. The keystone of Beauséjour's sustainability is the mixing of urban objectives and environmental issues. The project could be summed up as follows, urban objectives translated into an environmental and bioclimaticsensitive design. More over the advocacy planning will allow the inhabitants to take care of the plant heritage and contribute to the project. This aspect is still work in progress and needs to be improved, but it illustrates the will of going over the technocratic procedures [14]. The challenge of the tropical sustainable city is to combine three elements, classic urban issues, environmental concerns and advocacy planning. 


\section{References}

[1] Robert (R.), 1986. - Climat et hydrologie à la Réunion. Étude typologique et régionale des pluies et de l'écoulement, Thèse de doctorat, Université de Montpellier, $438 \mathrm{p}$.

[2] Emelianoff, Cyria. "Les agendas 21 locaux: quels apports sous quelles latitudes ?” Développement durable et territoires. Économie, géographie, politique, droit, sociologie no. Dossier 4 (May 31, 2005). doi:10.4000/developpementdurable.532.

[3] Lehmann, Steffen. "Green Urbanism: Formulating a Series of Holistic Principles.” S.A.P.I.EN.S. Surveys and Perspectives Integrating Environment and Society no. 3.2 (October 12, 2010). http://sapiens.revues.org/1057.

[4] Newman, Peter. "Green Urbanism and Its Application to Singapore.” Asia Research Institute, National University of Singapore no. WPS 151. Asian Working Paper Series (March 2011): 27 p.

[5] Shashua-Bar L., Hoffman M.E., Vegetation as a climatic component in the design of an urban street: An empirical model for predicting the cooling effect of urban green areas with trees Energy and building no. 31 (2000): 221-235.

[6] Wong, Nyuk-Hien, and Chen Yu. "The Urban Heat Island Effect in Singapore.” In Tropical Sustainable Architecture: Social and Environmental Dimensions, 181-199. 1st ed. Routledge, 2006.

[7] Sodhi, Navjot S., Clive Briffett, Lily Kong, and Belinda Yuen. "Bird Use of Linear Areas of a Tropical City: Implications for Park Connector Design and Management.” Landscape and Urban Planning 45, no. 2-3 (October 30, 1999): 123-130. doi:10.1016/S0169-2046(99)00028-6.

[8] Grimmond, C.S.B, M. Roth, T.R. Oke, Y.C. Au, and M. Best. "Climate and More Sustainable Cities: Climate Information for Improved Planning and Management of Cities.” Procedia Environmental Sciences 1 (2010): 247-274.

[9] Mittermeier R.A., da Fonseca G.A.B., Hoffman M., Pilgrim J., Brooks T., Gill P.R., Mittermeier C.G., Lamoreux J., Hotspots revisited : Earth's biologically richest and most endangered terrestrial ecoregions, CEMEX, Conservation International, 2005.

[10] Kheng Soon, Tay. "Rethinking the City in the Tropics: The Tropical City Concept." In Tropical Architecture Critical Regionalism in the Age of Globalization, 266-307. Chichester: Wiley-Academy, 2001.

[11] Arnstein, Sherry R. “A Ladder of Citizen Participation,” JAIP, Vol. 35, No. 4, July 1969, pp. 216-224.

[12] Le Moniteur, Hors-série “Aménagement 2009” p 43

[13] Rogers, Richard George, and Philip Gumuchdjian. Cities for a Small Planet. Boulder, Colo.: Westview, 1998.

[14] Bourdin, Alain. L'urbanisme D'après Crise. Monde En Cours. La Tour d'Aigues: Editions de l'Aube, 2010. 